\title{
P01.07. The Chinese herbs Chuan Bei Mu and Huang Qin can produce dose-dependent biphasic response in endometrial cancer cells
}

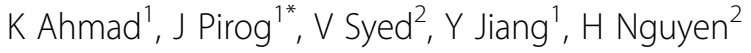 \\ From International Research Congress on Integrative Medicine and Health 2012 \\ Portland, Oregon, USA. 15-18 May 2012
}

\section{Purpose}

We shortlisted four commonly-used herbs from the Chinese Materia Medica, including Lian Qiao (Forsythiae Fructus), Chuan Bei Mu (Fritillariae cirrhosae Bulbus), Bai Zhi (Angelicae dahuricae Radix) and Huang Qin (Scutellariae Radix) due to suggestions in classical writings that they could possess antitumor properties.

\section{Methods}

We were interested in testing the herbs' cytotoxic potential and used Ishikawa endometrial cancer cells. Cells were incubated for 24 hours in varying concentrations $(1-500 \mu \mathrm{g} / \mathrm{ml})$.

\section{Results}

We found that at low doses Huang Qin induced cytotoxicity $(1 \mu \mathrm{g} / \mathrm{ml})$, but at high doses, $50-300 \mu \mathrm{g} / \mathrm{ml}$, the same herb induced cell proliferation. Chuan Bei $\mathrm{Mu}$ exhibited a similar biphasic response with cytoxicity at $1-200 \mu \mathrm{g} / \mathrm{ml}$ but proliferation at $400 \mu \mathrm{g} / \mathrm{ml}$. Data on Lian Qiao was scattered but the herb induced cytotoxicity at low doses from 1-10 $\mu \mathrm{g} / \mathrm{ml}$ and less significantly at high doses. Bai Zhi was the only herb that did not induce cytotoxicity in endometrial cancer cells.

\section{Conclusion}

Taken together, the preliminary data underscore the effect of these herbs as bioactive compounds with chemotherapeutic potential, and contrastingly of their ability to enhance cancer cell growth or confound the effect of chemotherapeutic agents.

${ }^{1}$ Northwestern Health Sciences University, Bloomington, USA

Full list of author information is available at the end of the article

\author{
Author details \\ ${ }^{1}$ Northwestern Health Sciences University, Bloomington, USA. ${ }^{2}$ Uniformed \\ Services University of the Health Sciences, Bethesda, USA.
}

Published: 12 June 2012

doi:10.1186/1472-6882-12-S1-P7

Cite this article as: Ahmad et al:: P01.07. The Chinese herbs Chuan Bei $\mathrm{Mu}$ and Huang Qin can produce dose-dependent biphasic response in endometrial cancer cells. BMC Complementary and Alternative Medicine 2012 12(Suppl 1):P7.
Submit your next manuscript to BioMed Central and take full advantage of:

- Convenient online submission

- Thorough peer review

- No space constraints or color figure charges

- Immediate publication on acceptance

- Inclusion in PubMed, CAS, Scopus and Google Scholar

- Research which is freely available for redistribution 